DOI: 10.33766/2524-0323.90.59-69

УДК 94(470+571):349.42:336.77

Д. А. Селіхов,

кандидат юридичних наук, доцент кафедри теорії та історії держави і права

Дніпропетровського державного університету внутрішніх справ

(м. Дніпро, Україна)

e-mail: dmitriy.selihov1969@gmail.com

iD https:/ / orcid.org/0000-0003-2180-1010

\title{
УДОСКОНАЛЕННЯ ПРАВОВИХ ОСНОВ СИСТЕМИ ДРІБНОГО СІЛЬСЬКОГОСПОДАРСЬКОГО КООПЕРАТИВНОГО КРЕДИТУ В УКРАЇНІ ЗА ЧАСІВ СТОЛИПІНСЬКИХ РЕФОРМ (1906-1917рp.)
}

У статті досліджено процес формування правових основ системи дрібного сільськогосподарського кооперативного кредиту, початок якому було покладено «Зразковим статутом» ощадно-позичкових товариств, схваленим Міністерством фінансів Російської імперії 19 липня 1871 р. Згідно з цим правовим актом, основним завданням ощадно-позичкових товариств було формування обігових коштів, необхідних дрібним сільськогосподарським товаровиробникам з ряду непривілейованих станів для купівлі насіння, худоби, знарядь праці, без чого господарювати на землі практично неможливо. У наступні десятиліття імперський центр вжив цілу низку актів нормативного характеру, 3 тим щоб унеможливити масове розорення широких мас так званих «сільських станів», які, як відомо, були основними платниками податків i, відповідно, від яких залежало формування державного бюджету.

Наступним, після 1871 року, ключовим етапом у становленні кооперативного кредиту на українських землях Російської імперіїбули: «Положення про установидрібного кредиту» від 1 червня 1895 року та «Положення про установи дрібного кредиту» від 7 червня 1904року. Останній законодавчій акт став своєрідним фундаментом цілої низки правових актів 1906 - 1917 років, результатом яких у тогочасній країні сформувалась чітка система кредитної кооперащії, якою досить активно користувалися непривілейовані стани від початку столипінських перетворень і до відомих сощіальних потрясінь 1917року.

Ключові слова: Російська імперія, Україна, кредит, ощадно-позичкові товариства, кредитні товариства.

Постановка проблеми. Після реалізації законодавчих актів щодо колишніх кріпосних (1861 р.), удільних (1863 р.) та державних (1866 р.) селян на території підросійської України (Київська, Подільська, Волинська, Полтавська, Харківська, Чернігівська, Катеринославська, Херсонська і Таврійська губернії) сформувалася кількамільйонна маса малоземельних (1893842), середняцьких (699 286) та заможних (397 318) родин, які належать до так званих «сільських станів» [6, с. 57]. Переобтяжені чисельними податками та натуральними повинностями основна маса дрібних сільськогосподарських товаровиробників відчувала гостру потребу в обігових коштах, що, власне, і зумовило формування в українських губерніях кредитної кооперації, відомої в історико-економічній літературі як «ощадно-позичкові» та «кредитні товариства», знайомство з діяльністю яких має неабияке значення для розвитку кредитної кооперації в сучасних реаліях.

() Сєліхов Д. А., 2020 
Аналіз останні х досліджень і публікацій. В останні десятиліття сільськогосподарський кредит Російської імперії кінщя XIX - початку XX ст. загалом, так і дрібний кооперативний, зокрема, позначений цілою низкою досліджень, серед яких особливої уваги заслуговують праці І. Витановича [1], С. Б. Коваленка [2], Ю. Шишута [3], В. І. Марочко [4] та ряду інших дослідників. Серед сучасних авторів звертає цікава й монографії М. А. Якименка, О. М. Красніковії, О. М. Кубецької [5], у яких проаналізовано правові аспекти функціонування дрібного кооперативного кредиту та визначено його вплив на економічний стан дрібних сільськогосподарських товаровиробників. Проте вважаємо, що дана проблематика ще далека від повного висвітлення. Особливо це стосується епохи столипінських реформ.

Формулювання цілей. Враховуючи це, автор поставив собі за мету з'ясувати процес вдосконалення правових основ системи дрібного сільськогосподарського кооперативного кредиту на українських землях Російської імперії після початку (у 1906 р.) відомих столипінських аграрних перетворень.

Виклад основного матеріалу. Першим законодавчим актом, покликаним регулювати діяльність ощадно-позичкових товариств є підстави вважати «Зразковий статут» 1871 року, тоді як у 1895 році було започатковано процес регулювання діяльності кредитних товариств, які, на відміну від ощадно-позичкових об'єднань, створювались не за рахунок пайових внесків членів кооперативу, а за допомогою позичок Державного банку та створеного ним Управління в справах дрібного кредиту. Проте ключовим законодавчим актом, на основі якого формувалася ціла низка правових актів щодо дрібного кредиту епохи столипінських реформ було, звичайно, затверджене імператором «Положення про установи дрібного кредиту» від 7 червня 1904 року [8, № 24737]. Стаття 2 даного «Положення» відносила до числа установ дрібного кредиту не лише ощадно-позичкові та кредитні товариства, але й сільькі і волосні громадські ощадно-позичкові каси, земські каси дрібного кредиту та сільські банки. До ряду найпомітніших нововведень цього закону належить норма, що дозволяла дрібним кооперативом об'єднуватися в союзи. Відповідно до мети даної публікації, ми зосередимо свою увагу лише на найбільш розповсюджених в українських губерніях (на рубежі XIX ст. - початку XX ст.) кооперативних об'єднаннях ощадно-позичкових та кредитних товариствах. Законодавчі акти кінщя XIX - початку XX ст. регулювали лише найпринциповіші моменти в діяльності кредитної кооперації, як то: 1) загальні положення; 2) операції установ дрібного кредиту; 3) облаштування установ дрібного кредиту; 4) керівнищтво справами дрібного кредиту. Відповідні норми права передбачалось деталізувати у відповідних «Зразкових статутах». Саме в них закон передбачав порядок утворення основного капіталу; дозволені операції; порядок кредитування членів товариства та умови повернення позичок; способи забезпечення позичок; умови прийому та повернення внесків; максимальний обсяг зобов'язань члена кооперативу; спосіб нагромадження основного й запасного капіталу; порядок звітності та зберігання наявних коштів; склад правління кооперативу, а також обов'язки окремих його органів i, нарешті, порядок закриття установи та ліквідації їі справ [8, ст. 20]. Кооперативні установи дрібного кредиту мали право видавати позики як на основі особистої довіри, так і за умови наявності поручителя або застави господарських виробів чи інвентаря. 
Видача позик, розмір яких не повинен був перевищувати четвертої частини оцінки заставленого майна, мала певний термін, який залежав від мети кредиту: до одного року - при видачі позички для поповнення обігового капіталу; до трьох років - на купівлю інвентаря, і до п'яти років - на господарське поліпшення [8, ст. 11]. Поняття «господарське поліпшення», «Статут сільського господарства» 1886 року видання тлумачив досить широко. Під цим терміном законодавець розумів застосування більш досконалих знарядь праці; удосконалення поля; зрошення; розведення луків; розвиток садівництва і виготовлення сухофруктів; поліпшення виноградарства та виноробства; розведення мануфактурних рослин; розведення лісів; бджільнищтво; поліпшення якості сільськогосподарських тварин; будівництво млинів, каналів та колодязів; відкриття різних фабрик; рибальство на морських берегах, тощо [9, ст. 32]. Після введення в дію закону від 7 червня 1904 року в зразкові статути ощадно-позичкових товариств циркулярами Міністерства фінансів від 14 вересня 1905 року, 24 листопада 1905 та 14 березня 1911 року були внесені зміни, якими було уніфіковано дрібний кооперативний кредит [10]. Після внесених змін Статути обох вищезгаданих типів товариств мало чим відрізнялись один від одного. Принщиповим залишалося лише наявність в ощадно-позичкових товариствах паю чи його відсутність у кредитних об'єднаннях. Для прикладу наведемо зміст ст. 28 обох типів товариств. У статуті кредитного товариства читаємо: «Громадські і приватні установи, які дали товариству позичку до основного капіталу, не мають права вимагати іï повернення», «наявність інших умов чи термінів повернення позички в основний капітал може бути допущене не інакше, як після схвалення Управлінням у справах дрібного кредиту». У Статуті ощадно-позичкового у тій же ст. 28 слово у слово повторено зміст щойно наведеної аналогічної статті кредитного товариства [11, с. 333].

Правозастосовча практика законодавства щодо ощадно-позичкових та кредитних товариств показала очевидні переваги другого зщойно згаданих типів кредитної кооперації насамперед через те, що в кредитних кооперативах основний капітал формувався не з пайових внесків, а за рахунок зовнішніх запозичень при активному сприянні Державного банку. Такз 1869 року, коли на території підросійської України виникло перше ощадно-позичкове товариство, до 1 січня 1908 року в 236 таких кооперативах нараховувалось уже 143081 особа. Хоч перше кредитне товариство виникло майже на 30 років пізніше (1897 р.), на 1 січня 1908 р. у 491 такому об'єднанні було 211036 членів, або майже в півтора рази білыше (147 552). Якщо ощадно-позичкові товариства за 39 років видали своїм членам позик на загальну суму 11110 тис. руб., то кредитні лише за 11 років своєї діяльності - 7512 тис. руб. [12, с. 42]. Члени обох типів кооперативу використовували отримані позички практично на одні й тіж цілі, що видно з відповідної статистики по Полтавській губернії, де дрібна кооперація посідала чи не найвизначніше місце в усій Російській імперії. Найбілыше коштів було використано на купівлю робочої худоби (32 \% у кредитних і 26 \% в ощадно-позичкових товариствах). Далі йдуть: купівля землі (відповідно 23 \% і 14 \%); оренда землі (13 \% і 5 \%). Усе інше не перевищувало кількох відсотків [13, с. 28].

Кредитними товариствами Полтавщини в 1914 році було куплено різного товару на загальну суму 454779 руб., тоді як ощадно-позичковими майже вдвічі менше - 263258 руб. У наступному, 1915 році, відповідні цифри білыш як подвоїлись: 
1151173 руб. та 1054892 руб. [14, с. 518]. Новим явищем у діяльності кредитної кооперації в період столипінської аграрної реформи було утворення спільних установ дрібного кредиту, рішення про які було ухвалено на Полтавському з'їзді представників установ дрібного кредиту 6-8 травня 1912 року [15, с. 8]. Звичайною справою для епохи столипінських реформ стали систематичні наради установ дрібного кредиту в межах певного регіону. Так у різних містах Полтавської губернії з 1908 до 1913 роки було проведено 9 таких нарад. Стількома ж нарадами відзначилась Катеринославська губернія. Вісім подібних нарад провели київські кооператори і п'ять волинські [16].

У роки столипінської аграрної реформи дрібна кредитна кооперація не лише зміцніла організаційно, але й розширила сферу своєї діяльності, активно включившись у посередницькі операції. У постанові Полтавського з'їзду установ дрібного кредиту читаємо таке: «Посередництво повинно ставити перед собою за мету постачання населенню сільськогосподарських знарядь і машин; купівлю через їх спілки живого і мертвого інвентаря; постачання кустарям і ремісникам доброякісного матеріалу по доступній ціні; оренду землі з наступною здачею їі окремими ділянками членам товариства».

3'їзд засудив діяльність земських кас дрібного кредиту в тому вигляді, у якому вони після згадуваного раніше законодавства 1904 року діяли в Полтавській та інших губерніях, На думку делегатів 3'їзду, земські каси практикують «роздачу грошей там, де кредитна кооперація привчає населення до ефективного використання кредиту в господарських цілях» [15, с. 12]. Грунтуючись на такій точщі зору щодо земських кас дрібного кредиту, які надавали кошти під 7-8 \% річних, а кооперативні установи під 12 \% [21, арк. 115], з'їзд у своїм ухвалі кваліфікував діючі каси, як гальмо в розвитку кредитних кооперативів. На думку делегатів, земські каси повинні своїм безпосереднім завданням вважати сприяння розвитку сільської кооперації. Якщо ж говорити про кредитні операції, то вони, на думку полтавських кооператорів, мають стосуватися лише колективних позичальників, тобто кооперативів. Для забезпечення якнайтіснішої співпраці земства і кооператорів доцільно було б «вважали делегати згаданого з'їзду включити до складу «земських економічних нарад представників установ дрібного кредиту» [15, с. 13]. Ідея щодо участі кредитної кооперації в посередницьких операціях знайшла підтримку Міністерства фінансів, що видно 3 відповідних його циркулярів місцевим відділенням Державного банку після завершення Полтавського з'їзду установ дрібного кредиту. 3 переписки керівника Полтавського відділення Державного банку М. Оглобліна та інспектора у справах дрібного кредиту А. Битуса видно, що банки загалом позитивно оцінили відповідні ухвали Полтавського з'їзду представників дрібного кооперативного кредиту від 6- 8 травня 1912 року. У цілому слід зазначити, що проведення подібного роду з'їздів стало організаційно-правовою формою щодо відстоювання інтересів кооперації перед органами публічної влади [17, с. 108].

Мотивуючи свою позицію цілковитої підтримки дрібної кооперації, вони звертали увагу свого петербурзького начальника на тому, що сільськогосподарські товаровиробники Полтавщини знаходяться під «гнітом торгових синдикатів, які диктують споживачам ціни з метою забезпечення собі надмірного прибутку» [18, арк. 32]. 
За її свідченням, окремі фірми по торгівлі сільськогосподарськими машинами й механізмами отримували під час продажу свого товару до 40 \% прибутку від їх ринкового вартості. Через те що окремі товариства не в змозі боротися $з$ такою несправедливістю, цілком закономірним, твердила резолюція цього з'їзду, є їх об'єднання в спілки.

Ще одним цілком новим напрямком кредитної кооперації в роки столипінських реформ було сприяння дрібним селянським господарствам у процесі збуту продукщії сільського господарства, насамперед зерна. Причому згаданий щойно полтавський з'їд виступив категорично проти скупки зерна з метою його перепродажу, адже в такому разі це вже буде «не посереднищтво, а спекуляпія». Розвиткові кредитної кооперації повинно було сприяти рішення уряду в особі міністра фінансів від 1 березня 1911 року щодо додаткових позичок в основні капітали кредитних товариств згідно зі статтею 3 відповідного закону від 19 липня 1910 року. 3 цього часу кредитні й ощадно-позичкові товариства могли розраховувати на державну позичку до 20 тис. рублів терміном до 20 років, на які можна було побудувати приміщення для зберігання кооперативного зерна. Ще одним кроком на шляху вдосконалення посередницьких операцій у Полтавській губернії був дозвіл губернського присутствія від 5 липня 1912 року передавати сільські хлібозапасні магазини в орендне користування кредитним товариствам та іншим кооперативним організаціям [18, арк. 60].

У роки столипінських реформ окремими нормативними актами регулювався порядок видачі кооперативними організаціями кредитів Департаментом землеробства Головного управління землеробства і землевпорядкування. Зокрема, 31 березня 1911 року було опубліковано циркуляр Головного управління щодо порядку кредитування кооперативів 3 метою купівлі ними прокатних пунктів машин і механізмів, які центральна влада стала формувати з метою підтримки індивідуальних селянських господарств, що перейшли від колективного до приватного землеволодіння. У випадку надання кредиту, сума якого мала становити не білыше за 300 рублів, місцевій державній адміністрації доручалось: 1) забезпечити за ними належний нагляд; 2) надати приміщення для зберігання машин і механізмів у закритому приміщенні; 3) утримувати машини в належному стані; 4) надавати машини й механізми в користування не лише членам кооперативу, але й усім бажаючим; 5) брати за користування машинами лише той розмір плати, який буде достатнім для функціонування прокатного пункту; 6) надавати щорічно протягом найближчих п'яти років Департаменту землеробства відповідні відомості про роботу прокатного пункту [8, арк. 36].

Практика функціонування кредитної кооперації показала очевидну ефективність і, відповідно, перевагу кредитних товариств над ощадно-позичковими, де принщип наявності паю гальмував як зростання числа таких кооперативів, так i ïx ефективність, хоч заборгованість по кредитах мала місце як в одних, так і в інших кооперативах. Згідно з законом від 7 червня 1904 року, поліція чи волосне правління повинні були приступити до стягненню боргу не за відповідним рішенням суду, а на основі письмової заяви установи дрібного кредиту. Ця норма права мала на меті забезпечити процес «швидкого й рішучого стягнення боргу» [20, с. 1]. I все ж недобросовісних позичальників у товариствах було немало, що дало підстави Комітету у справах дрібного кредиту від 7 травня 1912 року надати право інспекторам дрібного 
кредиту за результатом ревізії кредитного чи ощадно-позичкового товариства усувати «шкідливого члена правління від своїх обов'язків по керівнищтву кооперативом» [21, арк. 45]. Найпереконливішим свідченням ролі кредитної кооперації в економічному розвитку країни є неухильне зростання їі суспільного значення, на що звертало увагу багато громадських діячів початку XX ст. Так, наприклад, такий відомий свого часу кооператор, як В. А. Кільчевський нарахував 10 вигод кредитного товариства, серед яких: низький відсоток; не потрібно просити куркуля; відсутність витрат на горілку; не потрібно кланятись і принижуватись; відсоток для всіх однаковий; відсоток платити не до чужих рук, а товариству; гроші близько - у своєму селі; гроші отримуєш тоді, коли в них є невідкладна потреба; термін платежу є зручним; через товариство можна дешевше купувати й вигідніше продати в ході посередницьких операцій [23, с. 40]. Тож і не дивно, що позичками в установах кредитної кооперації користувались практично всі верстви тогочасного суспільства: селяни, козаки, міщани, дворяни та різночинщі [24, с. 137]. І все ж абсолютну більшість членів таких кооперативів складали дрібні товаровиробникиз числа селян і козаків. Так серед членів Жигайлівського кредитного товариства Сумського повіту з 351 члена кооперативу станом на 1917 рік не було жодного домогоспадаря із землеволодінням у 20 дес. і більше [25, арк. 11].

Висновки. Виходячи з вищевикладеного, є всі підстави зробити висновок про те, що центральні органи державної влади в роки столипінської аграрної реформи здійснили ряд помітних кроків на шляху до вдосконалення правових основ функціонування кредитної кооперації, уособленням якої на українських землях Російської імперії були кредитні й ощадно-позичкові кооперативи. Кредитна політика імперського уряду цілком узгоджувалась із новою аграрною політикою, центральною віссю якої була всіляка підтримка дрібних сільськогосподарських товаровиробників, які у 1902 та 1905 - 1907 роках активно підштовхували центральну владу до відповідних реформ в усіх сферах суспільного життя, спрямованих на те, щоб у майбутньому не допустити повторення антиурядових виступів, зберегти, таким чином, існуючий поділ суспільства на привілейовані (дворяни, чиновники, офіцери, купці, почесні громадяни й духовенство) та непривілейовані (селяни, козаки, міщани й робітники) стани. Однак проведені в 1906-1916 роках реформи виявились недостатніми для забезпечення стабільності і, відповідно, поступального розвитку країни на шляху прогресу. 3 погляду практичного використання досвіду функціонування дрібної кредитної кооперації в сучасних українських реаліях важливо знати найпринциповіші норми права, які регулювали кредитні операції на рубежі XIX-XX cт., які слід врахувати при вдосконаленні вітчизняного законодавства щодо кооперативних об'єднань, яке, як свідчить провозастосовна їх практика, ще далеке від ідеалу, адже в останні десятиріччя чисельність кредитних кооперативів в Україні практично не зростає, хоч потреба мешканщів України в дрібному кредиті $є$.

\section{Використані джерела:}

1. Витанович І. Історія українського кооперативного руху. Нью-Йорк, 1964. 686 с.

2. Коваленко С. Б. Кредитная инфраструктура сельского хозяйства царской России. Саратов: Издат. Центр Саратов. гос. Экономич. Академии, 1993. 186с. 
3. Шишута Ю. Правове становище кредитних кооперативів у Російській імперії наприкінщі XIX - на початку XX ст. / / Право Украӥни. 2012. № 12. С. 136-139.

4. Марочко В. I. Українська селянська кооперація: Історико-теоретичний аспект (1861-1929 рp.). K., 1995. 224 c.

5. Якименко М. А., Краснікова О. М., Кубецька О. М. Правове регулювання дрібного сіљськогосподарського кредиту та його економічне значення на українських землях Російської імперії. (1861-1917 рр.). Монографія. Полтава: РВВ ПДАА, 2019. 216 с.

6. Лещенко М. Н. Класова боротьба в українському селі в епоху домонополістичного капіталізму (60-90-ті роки ХІХ ст.) К.: Наукова думка, 1970. 304 с.

7. Пантелеймоненко А. О. Аграрна кооперація в Украӥні: теорія і практика: монографія. Полтава: РВВ ПУСКУ, 2008. 347 с.

8. Височайше утвержденное Положение об учреждениях мелкого кредита / / Полное собрание законов Российской империи (далі - ПСЗРИ). Собр. 3-є. Т.XXIV. СПб.: Гос. типография, 1904. №24737.

9. Устав сельского хозяйства. Том ХІІ. Часть 2. Издание 1886 года. - СПб: Гос. типогр., 1886. $103 \mathrm{c}$.

10. Образцовый устав ссудо-сберегательных товариществ, утвержденный министром финансов 14 сентября 1905 г., измененный 24 ноября 1905 г. и 14 марта 1911 г. и распубликованный в Собрании узаконений и распоряжений правительства 9 декабря. 1905 г. в № 51. - Полтава: электрич. типогр. М. Г. Амчиславского, 1914. 33 с.

11. Образцовый устав кредитних и ссудо-сберегательных товариществ// Положення об угреждениях мелкого кредита. Свод законов, том XI, часть 2, Раздел Х Устава кредитного, по Сводному продолжению 1912 года. Составил Н.С. Доброхотов. СПб.: Юридический книжный магазин Н.К. Мартынова, 1914. С. 313-395.

12. Статистический справочник по Югу Росии. Полтава: Электрич. типо- литогр. «И. А. Дохман», 1910. 76с.

13. Битус А. П. Учреждения мелкого кредита в Полтавской губернии за 1914 год// Полтавские агрономические известия. №1-й (10). 15 февраля 1916 г. - Полтава: Электрич. типлитогр. И. Л. Фришберга, 1916. С. 12-38.

14. Хуторянин. Орган Полтавского сельскохозяйственного общества. 1916. № 26-27. 625 с.

15. Полтавский съезд представителей учреждений мелкого кредита (6-9 мая 1912 года) // Вестникмелкого кредита Орган министерства финансов. СПб., 1913. № 5. С. 8-13.

16. Вестник мелкого кредита. 1912. № 11. 480 с.

17. Нестерович В. Ф. Ретроспективний аналіз сегментів українського лобіювання у дореволюційний період (до 1917 року). Вісник Луганського державного університету внутрішніх справ імені Е.О. Дідоренка. 2009. № 3. Ч. І. С. 107-119.

18. Державний архів Полтавської області. Ф. 1007. Оп. 1. Спр. І: «Циркуляры Министерства финансов и Полтавского отделения Государственного банка о взимании промисловых налогов, крестьянских ссуд и по другим вопросам, месячные финансовые отчеты товарищества». 170 арк.

19. Державний архів Сумської області. Ф. 400. Оп. 1. Спр. 5: «Циркуляры Главного управлення земледелия и землеустройства о материальной помощи кредитным товариществам». 42 арк.

20. Краинский В. В. Руководство к применению законов и правил при взыскании просроченних ссуд учреждениями мелкого кредита. СПБ.: Типогр. Ковенского, 1908. 65 с.

21. Російський державний історичний архів. Ф. 582. Оп. 6. Спр. 670: «Печатние материалы, наказы, инструкции, правила, циркуляры, наставления по вопросам, связанным с организацией и деятельностью учреждений мелкого кредита». 128 арк. 
22. Центральний державний історичний архів у м. Києві. Ф. 12. Оп. 1. Спр, 368: «Об организации мелкого кредита в России». 213 арк.

23. Кильчевский В. А. Какая разница между частным банком и кредитным товариществом (Из бесед на кооперативных курсах). Смоленск: Типо- литография С. Гуревич, 191349 c.

24. Статистический ежегодник Полтавского губернского земства на 1902 г. Полтава: Тип. И. А. Дохман и Л. Т. Фришберга, 1902. 201 с.

25. Державний архів Сумської області. Ф. 213. Оп.1. Спр. 13: «Дело Сумского отделения Государственного банка. Устав Жигайловского кредитного товарищества». 54 арк.

\section{References:}

1. Vitanovich, I. (1964) Istoriya ukrayinskogo kooperativnogo ruhu. Nyu-Jork. [in Russian].

2. Kovalenko, S. B. (1993) Kreditnaya infrastruktura selskogo hozyajstva carskoj Rossii. Saratov: Izdat. Centr Saratov. gos. Ekonomich. Akademii. [in Russian].

3. Shishuta, Yu. (2012) Pravove stanovishe kreditnih kooperativiv u Rosijskij imperiyi naprikinci HIH - na pochatku HH st. // Pravo Ukrayiny - Law of Ukraine. 12, 136-139. [in Ukrainian].

4. Marochko, V. I. (1995) Ukrayinska selyanska kooperaciya: Istoriko-teoretichnij aspekt (1861-1929 rr.). Kyiv. [in Ukrainian].

5. Yakimenko, M. A., Krasnikova, O. M., Kubecka, O. M. (2019) Pravove regulyuvannya dribnogo silskogospodarskogo kreditu ta jogo ekonomichne znachennya na ukrayinskih zemlyah Rosijskoyi imperiyi. (1861-1917 rr.). Monografiya. Poltava: RVV PDAA. [in Ukrainian].

6. Leshenko, M. N. (1970) Klasova borotba v ukrayinskomu seli v epohu domonopolistichnogo kapitalizmu (60-90-ti roki XIX st.) K.: Naukova dumka. [in Ukrainian].

7. Pantelejmonenko, A. O. (2008) Agrarna kooperaciya v Ukrayini: teoriya i praktika: monografiya. Poltava: RVV PUSKU. [in Ukrainian].

8. Visochajshe utverzhdennoe Polozhenie ob uchrezhdeniyah melkogo kredita (1904) // Polnoe sobranie zakonov Rossijskoj imperii (dali - PSZRI) - Complete collection of laws of the Russian Empire (hereinafter - PSZRI). Sobr. 3-ye. Vol. XXIV. SPb.: Gos. tipografiya, 24737. [in Russian].

9. Ustav selskogo hozyajstva. (1886) Vol. XII. Part. 2. SPb: Gos. tipogr. [in Russian].

10. Obrazcovyj ustav ssudo-sberegatelnyh tovarishestv, utverzhdennyj ministrom finansov 14 sentyabrya 1905 g., izmenennyj 24 noyabrya 1905 g. i 14 marta 1911 g. i raspublikovannyj v Sobranii uzakonenij i rasporyazhenij pravitelstva 9 dekabrya. 1905 g. v № 51 . (1914) Poltava: elektrich. tipogr. M. G. Amchislavskogo. [in Russian].

11. Obrazcovyj ustav kreditnih i ssudo-sberegatelnyh tovarishestv. (1914) Polozhennya ob ugrezhdeniyah melkogo kredita. Svod zakonov, tom XI, chast 2, Razdel X Ustava kreditnogo, po Svodnomu prodolzheniyu 1912 goda - Volume XI, Part 2, Section X of the Credit Charter, on the Consolidated Continuation of 1912. Sostavil N. S. Dobrohotov. SPb.: Yuridicheskij knizhnyj magazin N. K. Martynova, 313-395. [in Russian].

12. Statisticheskij spravochnik po Yugu Rosii. (1910) Poltava: Elektrich. tipo- litogr. «I. A. Dohman». [in Russian].

13. Bitus, A. P. Uchrezhdeniya melkogo kredita v Poltavskoj gubernii za 1914 god. (1916) Poltavskie agronomicheskie izvestiya, 1-j (10), 15 fevralya 1916 g. - Poltava agronomic news,1-j (10). February 15, 1916. 15 fevralya 1916 g. Poltava: Elektrich. tip-litogr. I. L. Frishberga, 12-38. [in Russian].

14. Hutoryanin. (1916) Organ Poltavskogo selskohozyajstvennogo obshestva - Body of the Poltava Agricultural Society, 26-27. [in Russian].

15. Poltavskij sezd predstavitelej uchrezhdenij melkogo kredita (6-9 maya 1912 goda). (1913) Vestnik melkogo kredita Organ ministerstva finansov - Bulletin of small credit Body of the Ministry of Finance. SPb., 5, 8-13. [in Russian]. 
16. Vestnik melkogo kredita - Bulletin of small credit Body, (1912), 11. [in Russian].

17. Nesterovich, V.F. (2009) Retrospektivnij analiz segmentiv ukrayinskogo lobiyuvannya u dorevolyucijnij period (do 1917 roku). Visnik Luganskogo derzhavnogo universitetu vnutrishnih sprav imeni E. O. Didorenka - Bulletin of Luhansk State University of Internal Affairs named after E. O. Didorenko, 3, part. I, 107-119. [in Ukrainian].

18. Derzhavnij arhiv Poltavskoyi oblasti. F. 1007. Op. 1. Spr. I: «Cirkulyary Ministerstva finansov i Poltavskogo otdeleniya Gosudarstvennogo banka o vzimanii promislovyh nalogov, krestyanskih ssud i po drugim voprosam, mesyachnye finansovye otchety tovarishestva». 170 ark. [in Russian].

19. Derzhavnij arhiv Sumskoyi oblasti. F. 400. Op.1. Spr. 5: «Cirkulyary Glavnogo upravlennya zemledeliya i zemleustrojstva o materialnoj pomoshi kreditnym tovarishestvam». 42 ark. [in Russian].

20. Krainskij, V. V. (1908) Rukovodstvo k primeneniyu zakonov i pravil pri vzyskanii prosrochennih ssud uchrezhdeniyami melkogo kredita. SPB.: Tipogr. Kovenskogo. [in Russian].

21. Rosijskij derzhavnij istorichnij arhiv. F. 582. Op. 6. Spr. 670: «Pechatnie materialy, nakazy, instrukcii, pravila, cirkulyary, nastavleniya po voprosam, svyazannym s organizaciej i deyatelnostyu uchrezhdenij melkogo kredita». 128 ark. [in Russian].

22. Centralnij derzhavnij istorichnij arhiv u m. Kieyvi. F. 12. Op. 1. Spr, 368: «Ob organizacii melkogo kredita v Rossii». 213 ark. [in Russian].

23. Kilchevskij, V. A. (1913) Kakaya raznica mezhdu chastnym bankom i kreditnym tovarishestvom (Iz besed na kooperativnyh kursah). Smolensk: Tipo-litografiya S. Gurevich. [in Russian].

24. Statisticheskij ezhegodnik Poltavskogo gubernskogo zemstva na 1902 g. (1902) Poltava: Tip. I. A. Dohman i L. T. Frishberga. [in Russian].

25. Derzhavnij arhiv Sumskoyi oblasti. F. 213. Op.1. Spr. 13: «Delo Sumskogo otdeleniya Gosudarstvennogo banka. Ustav Zhigajlovskogo kreditnogo tovarishestva». 54 ark. [in Russian].

Стаття надійшиа до редколегії 25.06.2020

Селихов Д. А., кандидат юридических наук, доцент кафедры теории и истории государства и права Днепропетровского государственнного университета внутренних дел (г. Днепр, Украина)

\section{УСОВЕРШЕНСТВОВАНИЕ ПРАВОВЫХ ОСНОВ СИСТЕМЫ МЕЛКОГО СЕЛЬСКОХОЗЯЙСТВЕННОГО КООПЕРАТИВНОГО КРЕДИТА В УКРАИНЕ ВО ВРЕМЕНА СТОЛЫПИНСКИХ РЕФОРМ (1906-1917 гг.)}

В статье рассмотрен процесс формирования правовых основ системы мелкого сельскохозяйственного кооперативного кредита, начало которому было положено «Примерным уставом» ссудо-сберегательных товариществ, утвержденный Министром финансов Российской империи 19 июля 1871 г. Согласно этого правового акта основным заданием ссудо-сберегательных товариществ было формирование оборотных средств необходимых мелким сельскохозяйственным товаропроизводителям из числа непривилегированных сословий для покупки зерна, скота, орудий труда без чего хозяйствовать на земле было практически невозможным. В следующие десятилетия имперский центр принял 
множество актов нормативного характера, для того чтобы исключить возможность массового разорения широких масс так называемьх «сельских сословий», от которых зависило формирование государственного бюджета.

Следующим, после 1871 года, ключевым этапом в становлении кооперативного кредита на украинских землях Российской империи были «Положение об учреждениях мелкого кредита» от 1 июня 1895 года и «Положение об учреждениях мелкого кредита» от 7 июня 1904 года. Последний законодательный акт стал своеобразным фундаментом многочисленных правовых актов 1906 - 1917 годов, результатом которых в государстве того время сформировалась четкая система кредитной кооперации, которой очень активно пользовались непривелигерованные сословия с начала стольпинских преобразований и до известных социальных потрясений 1917 года.

Ключевые слова: Российская империя, Украина, кредит, ссудо-сберегательные товарищества, кредитные общества.

Selikhov D.,

Candidate of Law Sciences, Associate Professor of Department of Theory and History of State and Law of Dnipropetrovsk State University of Internal Affairs

(Dnipro, Ukraine)

\section{IMPROVEMENT OF THE LEGAL BASIS OF THE SYSTEM OF SMALL AGRICULTURAL COOPERATIVE CREDIT IN UKRAINE IN TIME OF STOLYPIN REFORMS (1906-1917 YEARS)}

On the basis of historical-genetic, historical-comparative and historical-typological methods the process of formation of more effective legal bases of the system of small cooperative credit was investigated, the beginning of which was laid by the "Model charter" of savings and loan societies approved by the Ministry of Finance of Russian Empire on July 19, 1871. According to this legal act, the main task of savings and loan societies was the formation of working capital needed by small agricultural producers from among the unprivileged estates to buy seeds, livestock, tools, without which it was almost impossible to manage the land. In the following decades, the imperial center adopted a number of acts of a normative nature in order to prevent the mass ruin of the broad masses of the so-called "rural estates", which are known to be the main taxpayers and, accordingly, depended on the state budget.

The next key stage after 1871 in the formation of cooperative credit in the Ukrainian lands of the Russian Empire were: "Regulations on Small Credit Institutions" of June 1, 1895 and "Regulations on Small Credit Institutions" of June 7, 1904. The last legislative act became a kind of foundation for a number of legal acts of 1906-1917 years, as a result of which a clear system of credit cooperation was formed in the country, which was used quite actively by the underprivileged states from the beginning of the Stolypin transformations to the famous social upheavals of 1917 year.

The author of this report focused not only on the changes in the legal acts of the Stolypin reforms, but also on the socio-economic consequences of the amendments to the statutes of both savings and loan companies, which once again emphasizes their socio-political significance. Taking into account the broad source base of the research, which included not only the relevant legislation of the late XIX-early XX centuries, but also materials obtained during the study of relevant information in a number of regional state archives. 
The methodological principles of the research are based on the principles of historicism, scientificity and dialectical approach to historical phenomena, while the scientific novelty lies in a comprehensive approach to the process of forming a small cooperative loan in the Ukrainian lands of the Russian Empire. Based on the analysis of the abovementioned sources, little-known aspects of small credit cooperation and its impact on the economy of Russian Ukraine in the early XX century were discovered. The conclusions indicate the relevance of cooperative issues in modern Ukrainian realities, especially after the Verkhovna Rada adopted a law on land market.

Keywords: Russian Empire, Ukraine, credit, savings and loan societies, credit societies.

DOI: $10.33766 / 2524-0323.90 .69-76$

УДК 340.115: 615.1

О. С. Ховпун,

кандидат юридичних наук, доцент, завідувач кафедри кримінального права, процесу та криміналістики

Академії праці, соціальних відносин і туризму

(м. Київ, Україна)

e-mail: khovpun3322@gmail.com

iDhttps://orcid.org/0000-0002-5753-966X

\section{ЗНАЧЕННЯ ГЕРМЕНЕВТИЧНОГО МЕТОДУ АДМІНІСТРАТИВНО-ПРАВОВОГО ЗАБЕЗПЕЧЕННЯ ФАРМАЦІЇ}

Стаття присвячена з'ясуванню значення герменевтичного методу адміністративно-правого забезпечення фармації. Доведено, що застосування герменевтичного методу сприяє отриманню повноти тлумачення норм закону на рівні ідеї, тексту, промови. Встановлено, що герменевтичний методпізнання дозволяє проводити інтерпретацію текстів нормативних актів, інших правових джерел з урахуванням історичних, ідеологічних, економічних, психологічних, соціологічних обставин прийняття та застосування закону. Обгрунтовано, що розуміння, тлумачення й застосування фармацевтичного законодавства повинні бути обмежені абсолютною цінністю - життям люДини та їі здоров' ям.

Ключові слова: фармація, методи, герменевтика, герменевтичний метод, наукове дослідження.

Постановка проблеми. Отримання повноти результатів наукового дослідження можливе лише при одночасному застосуванні загальнонаукових та спеціальних методів наукового пізнання. Залежно від предмета правого дослідження, його змістового навантаження, значення для розвитку прав людини, держави обираються відповідні методи. Серед них виокремлюються найбілыш значущі, які можуть розкрити сутність конкретно визначеного предмета дослідження. Останнім часом найбільш часто застосовують герменевтичний метод, який дозволяє з' ясувати смисл юридичного тексту закону та окремих правових джерел. Притім слід констатувати наявність прогалин щодо методологічного забезпечення дослідження адміністративно-правового забезпечення фармації. Унаслідок цього виникає потреба у виявленні значення методології

(C) Ховпун О. С., 2020 